\title{
A Popperian Approach: Pre-service Teachers' Preparation In Teaching English to Young Learners
}

\author{
Yuli Astutik $^{1}$, Fabiola Dharmawanti Kurnia ${ }^{2}$, Ali Mustofa ${ }^{3}$ \\ Universitas Negeri Surabaya ${ }^{1,3}$ \\ Universitas Muhammadiyah Sidoarjo ${ }^{1}$ \\ STKIP PGRI sidoarjo ${ }^{2}$ \\ Email Correspondence: yuli.20006@mhs.unesa.ac.id
}

\begin{abstract}
Karl Popper's falsification epistemology theory that all science develops through conjectures and refutations have enormous implications for education, especially in teaching English as a foreign language (TEFL). TEFL to young learners is a challenge for pre-service teachers in non-home English countries. They should prepare to teach English while they also use English as a foreign language. Pre-service teachers focused on mastering language skills, whereas many preparatory processes they have to ensure before they take into the English teaching profession. Therefore, in this article, the authors assert that pre-service teachers should master linguistics proficiency, pedagogy knowledge, and literature as the means used in teaching English. Some theories and research findings have been discussed in teaching English to EFL children. However, the scope of discussion on pre-service teachers' preparation is fragmented among the uses of language skill and teaching discipline. Even they rarely explain how to teach language in a fun way through literary works. With a comprehensive literature review method, this article focuses more on conveying the author's ideas and thoughts discussing EFL pre-service teachers' preparation in teaching English to young learners with the Popperian approach. The popperian approach is considered to be more dynamic and open to ideas and opinions on policies in various fields, one of which is education.
\end{abstract}

Keywords: Popperian approach; Teaching English as a foreign language (TEFL), Pre-service Teachers; English for Young Learners.

\begin{tabular}{|c|c|c|}
\hline DOI & : & https://doi.org/10.24903/bej.v3i1.707 \\
\hline Received & : & January 2021 \\
\hline Accepted & : & January 2021 \\
\hline Published & : & February 2021 \\
\hline $\begin{array}{l}\text { Copyright and } \\
\text { License }\end{array}$ & : & $\begin{array}{l}\text { Authors retain copyright and grant the journal the right of first publication with } \\
\text { the work simultaneously licensed under a Creative Commons Attribution } 4.0 \\
\text { International License that allows others to share the work with an acknowledgment of } \\
\text { the work's authorship and initial publication in this journal. } \\
\text { (c) B }\end{array}$ \\
\hline
\end{tabular}




\section{INTRODUCTION}

Philosophy is an essential means for humans to solve problems experienced in life, including education. Education can be interpreted as basic guidelines for achieving a goal. The purpose of education has the same meaning as philosophy, including guiding, shaping, and nurturing towards wisdom (Harahap et al., 2019). Therefore, teachers should understand and apply this philosophy. Philosophy for education is a key to answering questions in all areas, including English education (Ernest et al., 2016).

As a foreign language in Indonesia, English is in demand because it is considered a prestigious international communication tool (De Swaan 2013). Starting from children to adults, Indonesian citizens are very open to the presence of English. This principle is the same as the theory of Open society put forward by Karl Popper, a philosopher born in Austria. One of the crucial characteristics of an open society is recognizing individual sovereignty and protecting individual rights and freedoms that every human being has. For this reason, tolerance of diversity, be it religious, racial, and ethnic diversity, including language, are values that must be upheld. The openness of Indonesian citizens to English as a foreign language as a bridge to interact and communicate has become a necessity (Popper, 2014; Gerson, 2019; Parvin, 2010). Therefore, learning English as a foreign language has been taught from an early age. Teachers' competence influences the excellent mastery of English by children in the field of teaching English.

Teaching English does not have to be taught by native speakers. However, it can be from EFL teachers trained to teach English to young learners (Garton et al., 2011; Copland, 2014). Pre-service teachers need to realize that language skills are fundamental to master to teach them to students. For this reason, pre-service teachers must be open-minded, seek, and find the knowledge of the concepts and principles of teaching English for young learners. In philosophy that a process of finding is called falsification. Popper introduced falsification as the criterion for demarcation and described the evolution of science as a series of hypotheses and refutations moving toward universal truth claims. 
The falsification of teaching English to learners as a foreign language tends to be considered problematic. This issue makes parents compete to send their children to expensive course institutions where the teachers are native. Whereas, there are so many English teachers of which Indonesians have advanced English skills. Unfortunately, not many of them are good at teaching English to young learners. Hence, various universities in Indonesia have provided programs in their curriculum to create pre-service teachers for young learners. Pre-service teachers are college students who are currently studying in the teaching field (Akiba, 2011). Some researchers state that a pre-service teacher is a teacher who has graduated from education and is carrying out an apprenticeship program as a prerequisite before becoming an actual teacher (Beck \& Kosnik, 2000; Kosnik \& Beck, 2009). A pre-service teacher is someone who is still at the learning stage in preparing to become a teacher in the future (Peacock, 2001; Hagger \& Malmberg, 2011). The process of preparing to become a professional teacher is critical. It is because what the teacher says will be accepted and imitated by a student. A teacher's mistake in teaching English will be a persistent problem in the future that will never be resolved. For example, when an EFL teacher teaches vocabulary such as "finger" (fing'gr), usually the EFL teacher pronounces it wrong, so it becomes "finger" (/ z /).

This teacher's initial mistake is the spearhead that will affect being remembered by children throughout their life because children are reliable imitators. An already imprinted mindset will usually be challenging to change. Besides, vocabulary choice must be close to children's context, like the environment in which they live and their objects. Therefore mastery in English linguistics is the main asset for an EFL teacher (Ladson, 1999; Timmerman, 20009; Feiman \& Buchmann,1986; Ladson, 2004; Pinter, 2017). It is in line with Popper's view. According to Popper (1966a), one of the exemplary teachers in his dream school, seemed to like him, Socrates. Socrates taught that a teacher could not give his students truth before being proved falsified because a teacher is a seeker of truth, not the owner of the truth. Socrates emphasized that teachers must instill a critical attitude in themselves and their students. 
Therefore, being a good and professional teacher in teaching English as a foreign language needs preparation skills (Samson \& Collin, 2012; De Jong \& Harper, 2005). Pre-service teachers must study at formal educational institutions or universities to get the recognition and license that they deserve to become professional EFL teachers in the future (Caber, 2009; Itoi, 2014). As universities in Indonesia, especially in the English language education program, have facilitated many pre-serviceEFL teachers teaching English courses to children. Since they are aware of the competition in an increasingly developing era, mastering English cannot be avoided. Unfortunately, English is sometimes feared by some EFL children to learn because the teacher teaches less creatively and tends to give children a stack of assignments from the textbook as homework and discuss them at the next meeting (Durriyah, 2014). The fear of students learning English and the lack of teachers preparing knowledge that is increasingly developing and only stops with their understanding are closed society's characteristics. According to Popper, closed societies find it difficult to accept new information and open their minds to receive it. From these issues, a pre-service teacher needs to learn how the art of teaching includes methods, strategies, and techniques in teaching English to young EFL learners called pedagogy (Gebhard, 2006; Richards \& Farrel, 2005). In implementing pedagogy, EFL teachers need appropriate tools to teach English based on their students' level. It would be impossible to provide reading material from famous literary works from England, such as Memoirs of a Survivor by Doris Lessing, 1974, because EFL children, let alone reading novels, read simple sentences need to struggle too. Thus, teachers must be more selective in choosing good literary works for young EFL learners. For this reason, pre-service teachers are also trained on how to adjust the appropriate teaching materials later, such as short stories about cultural awareness, fiction and nonfiction stories, and other literary works (Motteram, 2013; Li, 2013; Ghazali at al, 2009).

Hence, it can be underlined that people who want to become an EFL teacher for young learners cannot be underestimated. They need robust preparation and keep searching for the truth as an open society's features to become a teacher of English as a foreign language for young learners. The authors of this article have extracted and synthesized various sources of theory and research results as a rationale that discusses the philosophy of teaching English as a foreign language, approximately what and how pre-service teachers prepare to become EFL teachers for young learners in the future. Using Popper's falsification principle, this article explores that preparation to become a teacher can be seen from three main points: linguistics proficiency, pedagogy skills, and literary works for EFL young learners. 


\section{METHODOLOGY}

This article presents a visual summary in a description and maps through a comprehensive literature review method. The visual map explored by the authors is about linguistics proficiency, pedagogy, and the application of literary works that all EFL pre-service teachers should use in their preparation to become English to young learners' teachers. In conducting this literature review, the authors carried out several stages based on the theory of Onwuegbuzie \& Frels (2016), who stated seven stages in conducting a comprehensive literature review. However, in this article, the authors only took six stages and did not use one stage, namely expanding the search because this research focuses on finding sources from books and articles, not from media or other documents such as news and expert information. The following are the steps adopted by the authors.

First, exploring topics by the author's field and beliefs about the urgency of this theme to be raised. It because there is much research on the mastery of foreign languages for EFL children and analysis of the ability of EFL pre-service teachers, even though there is no theory that links the three main pillars of teaching English for EFL children and EFL teachers (teachers and students are both non-English speakers nonetheless they do the process of learning English). Second, initiating the search, the authors began the search for sources or references from various international books and journals on EFL pre-service teachers, teaching English as a target language, and teaching English for young learners. Step three is storing and organizing the information that has been collected from reference sources. The authors do not limit the publication year because the authors consider the book to be the primary source. Then for journals, the authors determine from 2010 to 2020 or the last ten years. The reason the authors take the ten-year limitation is that although there have been many similar literature reviews in recent years, none has yet touched on the fundamental pillars that must be mastered by pre-service English teachers for young learners, especially in English non-home country where English is a foreign language for both teachers and students.

The fourth step was selecting and deselecting information. The authors have picked more than 50 articles that fit this article's discussion from hundreds of articles. Furthermore, the authors analyzed and synthesized all information from those references to yield three slices of the subject, namely linguistics, pedagogy, and literature. Finally, the authors concluded and presented the data. 


\section{FINDINGS AND DISCUSSIONS}

The authors explore the three pillars that EFL pre-service teachers should master as their provision to become good teachers in the future.

\subsection{Linguistics Proficiency in EFL}

In this section of the discussion, the authors highlight the mastery of linguistics of pre-service teachers. There are several things that an English teacher must fulfill. First, teachers must master the science of language to have linguistic knowledge, which significantly influences the teaching behavior (Richard \& Reodgers, 2014; Zaarinabadi, 2014; Adger \& Christian, 2018). Second, teachers must master several sub-sciences of linguistics, for example, semantics; teachers who understand semantics-pragmatics can easily explain to students the difference between fires and burning (if not able to explain it means not fully understood) (Asrial et al., 2019; Hollie, 2017). Third, language teachers must be proficient in the language, both in speech, intonation, and grammar, and understand language speakers' culture to explain where English came from (Betz \& Huth, 2014; Saito \& Isaacs, 2016; Stanley \& Stevenson, 2017).

Many teachers understand linguistics; however, they are not very good at speaking English. With this model of English teacher, students are directed to essence and understanding rather than skill. On the other hand, some teachers have good English proficiency but do not understand linguistics (Li \& Liu, 2020; Saafin, 2019). As a result, the teacher does not know what they are teaching because the material being taught relies heavily on books or dictionaries (Shanahan, 2020). Therefore, since taking pre-service education, teachers must analyze their strengths and weaknesses regarding their understanding and mastery of linguistics. So that they can focus more on fixing what is the problem. The linguistic indicators that must be studied by pre-service English language teachers are at the level of Phonology, Morphology, Syntax, Semantics, and Discourse (El-Naggar et al., 2020; Murphy et al., 2020).

Will pre-service teachers teach these linguistic indicators to EFL young learners later? Surely not (Mizell, 2020; Darwis \& Hasanah, 2020). Pre-service teachers must master them to prepare themselves as English teachers in the future. A good English teacher must master language skills and have to know the language knowledge (Perihan \& Mehmet, 2020). One day if they face barriers in the teaching process, they would overcome the problem. The following is an explanation of the linguistic indicators (figure 1). 


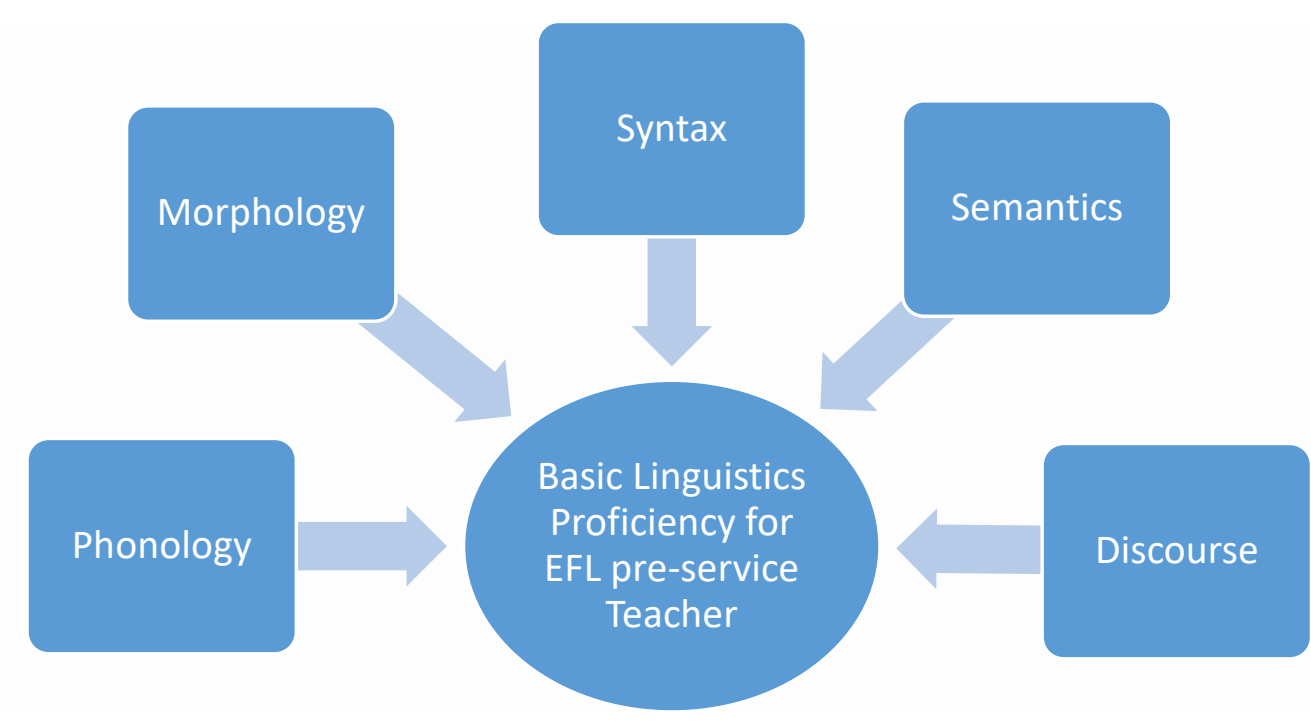

Figure 1. Linguistics Proficiency in EFL

Etymologically, phonology comes from two other Greek words, a phone, which means "sound," and logos, which means "knowledge." So the literal definition of phonology is "the science of sound." Phonology is a part of linguistics that studies sound. The first object of a phonological study is the sound of language, which is called the sound system (phonetics) (Yallop \& Fletcher, 2007). Thus, phonology is a branch of linguistics that studies language sounds, their formation, and change processes. Therefore, a pre-service EFL teacher should know before they teach English to their students. How is it possible for language teachers to practice language skills if they do not master phonology? For instance, the word target is pronounced / 'tärgət/ not /target/ (Lysvik, 2020; Babatsouli, 2020).

The word morphology comes from the Greek word 'morphe,' which is combined with 'logos,' morphe means to form, and logos means to form, and logos means science, so based on the meaning of its constituent elements, the word morphology means knowledge of word forms or word-formation. Morphology, or the science of word forms, is a linguistics branch that studies how a word or a morpheme is formed as a grammatical unit. Morphology also studies the effect of changing word forms on the meaning of a word. In other words, morphology studies and analyzes the structure, form, and classification of words.

In linguistics, the word syntax comes from Greek, which is a combination of syn words that means "together," and the word taxis, which means "series" "sequence." So the syntax is one of the branches of linguistics that studies the rules that determine how words form phrases and phrases form sentences. Etymologically, the syntax term puts together words into groups of words or sentences and groups of words into sentences. It examines how sentences are formed, and language users use a special variation to form elements in 
sentences. Several parts of the sentence structure in syntax that the writer will explain are subject, verb, object, complement, and adverb.

Semantics comes from the Greek Sema, a noun meaning "sign" or "symbol." The verb is Semaino, which means "to mark" or "to symbolize." What is meant by a symbol or sign here as the equivalent of the word is a linguistic sign.

Semantics can be defined as the science of meaning or meaning, one of three language analysis levels: phonological, grammatical, and semantic. The word semantics is agreed as a term used for linguistics, which studies the relationship between linguistic signs and the things they signify, or in other words, a field of study in linguistics that studies meaning or meaning in language.

The word discourse comes from Latin, namely "discourse." This word refers to the word conversation (conversation) or speech. We can also define discourse as an extension of language (especially in oral) that is broader than a sentence or is a coherent unit such as argument or narrative. According to Zellig Harris, a modern linguist who studies the relationship between sentences, which is called the term discourse. It is what led to the emergence of the term discourse analysis. Discourse analysis is a derivative of applied linguistics. Discourse analysis is related to evaluating text or discourse to determine the form or pattern of communication and other related matters that cannot be explained in grammar (Carter, 1993: 23). Another definition of discourse analysis is that discourse analysis is a form of study that examines and analyzes a language, both spoken and written. Discourse is a combination of text and context. In other words, a text can be called a discourse if there is a context.

\subsection{Pedagogy Knowledge as Pre-service Teachers Groundwork}

In the world of education, a teacher must master the art of teaching in which there are strategies (methods and techniques); this is called pedagogy (Karabuz \& Ogan, 2020). Teaching English must be following its application, whether as a second language or a foreign language (Setiyadi, 2020). Both need a teacher who is skilled in teaching. Some teachers are good academically but are not creative in the classroom. In contrast, academically mediocre teachers have good skills when teaching in class. Mastery of pedagogy does need to be honed when pre-service teachers are still studying at university as pre-service English teachers (Teo, 2019). 
Dealing with teaching methods, strategies, and techniques, the philosophy of teaching English as a foreign language is driven by the knowledge and its application of pre-service teachers. The three slices in the pedagogy can be illustrated in Figure 2.

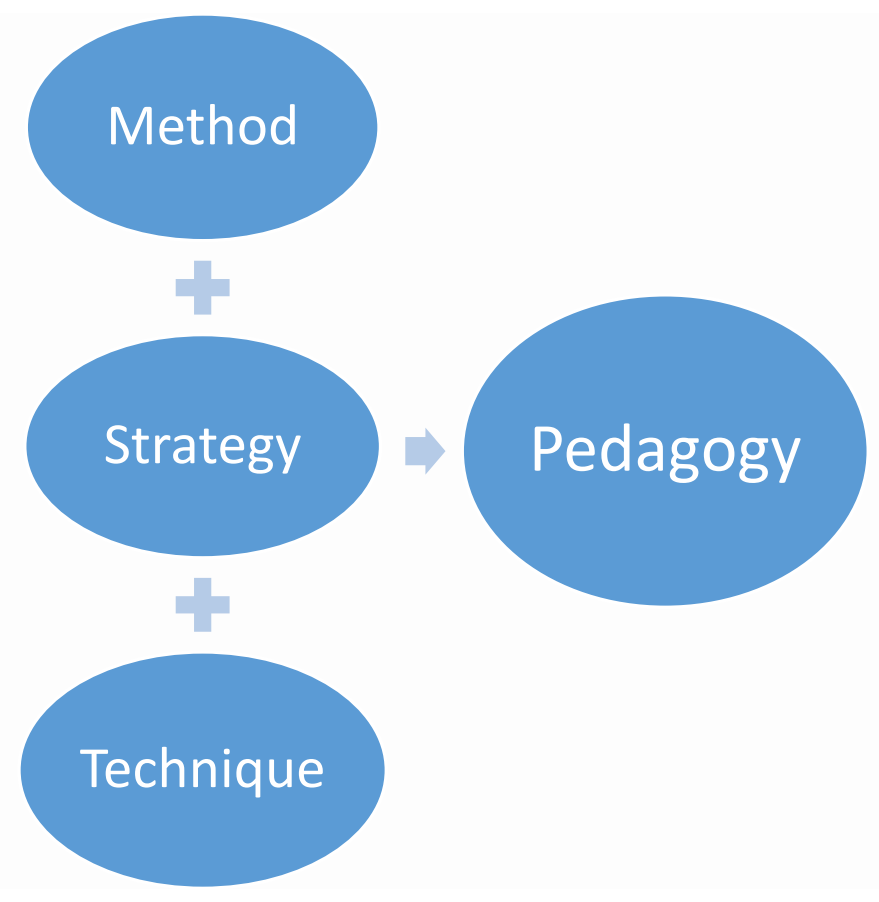

Figure 2. Pedagogy Knowledge as Pre-service Teachers Groundwork

In the pedagogy, there are learning strategies that must be mastered by a teacher. The teachers can choose approaches to deliver learning material that makes students readily absorb and understand the target language learning. The learning strategy contains an explanation of the teacher's methods and techniques during the teaching process. It means method and technique are part of the learning strategies, referred to as learning pedagogy. (Zhang et al., 2019; Huang et al., 2019; Nind \& Lewthwaite, 2020; Csíkos \& Szitányi, 2020; Pentury \& Anggraeni, 2019).

Learning strategies are activities designed as learning plans (Torres, 2020). In the learning strategy, two parts of the activity cannot be separated, methods and techniques (Oxford, 2016; O'MALLEY et al., 1985). The authors state that the strategy is a significant milestone before the implementation of learning methods and techniques. The learning strategy is conceptual to implement; specific learning methods must be used (Powell, 2015). In other words, the strategy is "a plan of operation achieving something" while the method is "a way in achieving something" (Wina Senjaya, 2008; Widyawati, \& Usman, 2019).The method is a way used by the teacher to implement strategies that have been prepared in the form of real and practical activities to achieve learning goals (Suparsa, 2017; Numonjonov, 2020; Brandt, 2020, Setiyadi, 2020). Several learning methods can be used to implement 
learning strategies in teaching English as a foreign language to children, such as reading methods, Audio lingual method, visual method, total physical response, and field study. Techniques are how the teacher implements a specific method (Freeman, 2000; Freeman \& Anderson, 2019). Various techniques teach EFL, such as song and game, conversation techniques, direction techniques, project techniques, cooperative techniques, and problemsolving techniques.

\section{Literary Works as a Mean of Teaching}

After strengthening mastery of linguistics and pedagogical skills, EFL pre-service teachers must also have tools as the ordnances when teaching English as a foreign language to children. Ideally, they must also know how to implement it while carrying out the English teaching process. Thus, their preparation to become real teachers is even more convincing. Figure 3 shows that literary works can help the teacher apply their linguistics proficiency and pedagogical knowledge in teaching EFL to young learners.

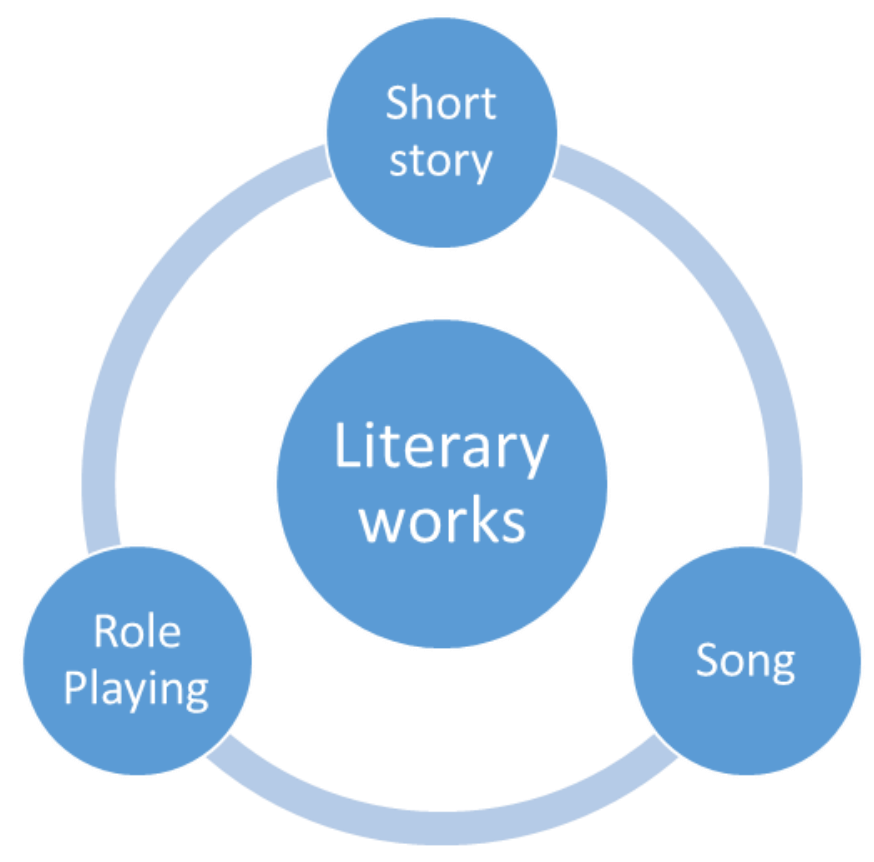

1. Short story

Figure 3. Literary Works as a Mean of Teaching

Short stories, both fiction and nonfiction, are the highest source for observing language and human life culture. In a fictional short story, the storyline characters usually act with symbols and stories in everyday life. Short stories reflect and illuminate human life (Sage 1987: 43). The inclusion of short fiction in EFL learning has the following educational advantages (Ariogul 2001: 11-18): 
1. It makes students' reading assignments easier because they are short and straightforward when compared to other literary genres,

2. Broaden the advanced level of the reader's world view of different cultures and different groups of people,

3. Provides more creative, encrypted, and challenging text that requires personal exploration supported by existing knowledge for advanced level readers, Motivates students to read because it becomes authentic material, Offers a world of magic and a world of mystery

4. Allow students to use their creativity,

5. Promotes critical thinking skills,

6. Facilitating the teaching of foreign cultures (for example; serving as a valuable instrument in gaining cultural knowledge from selected communities),

7. Make students feel comfortable and free,

8. Helping students who come from various backgrounds to communicate with one another because of its universal language,

9. Helping students to move beyond the visible meaning and dive into the more basic meaning,

10. It serves as a perfect vehicle for helping students understand their position by transferring this acquired knowledge to their world.

In short, the use of short stories is a beneficial technique in foreign language classes. Short stories make students' reading assignments more straightforward and more enjoyable because the stories offered are close to children's lives. Besides, teachers' reach is more comfortable because teachers can use short recitations suitable for their students. An essential feature of short fiction stories is their universal value. To put it differently, students worldwide have experienced stories and can relate them to them. Besides, short fiction, like all literary genres, contributes to developing cognitive analytical abilities by bringing the full value to a situation's density in every place and moment (Sage 1987: 43).

\section{Role Playing}

Pre-service teachers must also understand another strategy in implementing literary work, namely role-playing. Some experts define role-playing as a learning method using techniques to demonstrate it. Wicaksono (2016) states that the role-playing method has two kinds of definitions. First, role-playing is a play activity. It means that some players and characters play a particular role. The role is following the characters that have been written in 
the script. The purpose of playing this role is to provide entertainment to others. Second, the role-playing method is a sociological activity in which the patterns of behavior shown by a person are determined by the social norms that live in society. Discussing this method, a preservice teacher must understand how to implement it. What will be taught to students is not only theory but also what learning English by role-playing can be conveyed well. Roleplaying is very fun for children as long as they can prepare carefully, starting from the story script, stories, and characters that the students will play.

Mastery of this method is also crucial for pre-service teachers, especially for nonnative English children. There are several stages for teachers in implementing role-playing. First, teachers must understand the conditions of their students. To what extent their mastery of English due to role-playing requires students' proficiency in speaking skills. Of course, international elementary school students' speaking skills in big cities are different from those of elementary school students in the regions. Although students in both primary school types use English as a foreign language, they have a very different learning experience. While international elementary school students get a good curriculum for English subjects, elementary school students in the regions tend to get English courses as local content lessons. Thus, using English for elementary school students in the regions is not as frequent as elementary school students in international schools. Everyone knows that language skills will be more comfortable to master by practicing them both inside and outside the classroom.

The implementation of role-playing methods may be more efficiently provided to international elementary school students. Then what if this is implemented for elementary school students in the regions. Before becoming a teacher, pre-service teachers should prepare to implement this role-playing method. The following are the stages of the roleplaying method adapted from Tarnoto et al. (2016).

1. Create a comfortable atmosphere and remind children of their own experiences to identify themselves with the story's characters. To prepare children to listen and pay attention (an essential part), the teacher stimulates them by asking questions to solve problems.

2. After the children have expressed their opinion, the teacher can begin to choose the child who will play the role.

3. The teacher helps to describe the initial scene and prepare the equipment.

4. Convince the child to sit quietly and pay attention. 
5. The teacher prepares an English story script that the students will play. The story script must be simple, according to the theme of elementary school learning.

6. The teacher does a simulation of the story in English.

7. The teacher must guide students in reading the story script before they are sure that they will appear with the story characters that have been previously shared.

8. Memorizing is not recommended, but because this role-playing method is specific to English, students can memorize story scripts.

9. Children are free to explore the scene as they wish.

10. Invite the children to evaluate. The teacher must be careful because no scene is considered wrong. The teacher tries to get another opinion from all students.

11. Teachers can select new players and prepare the stage again.

12. Teachers encourage children to share their own experiences. The teacher helps the child conclude together with the core themes of the purpose of role-playing.

From the stages of the role-playing method above, every detail must be mastered by the pre-service teacher. Furthermore, pre-service teachers can explore their creativity in making simple story scripts in English.

\section{Song}

Songs are one of the literary works that are very common for all learners. Of course, for elementary school students, songs are fun things that always make them feel comfortable learning English. Songs are straightforward to sing by anyone. However, performing a beautiful song that is easy for students to follow can only be done by a cheerful and skilled teacher. It is highly discouraged for teachers to sing songs with a sad face. Therefore, in addition to memorizing various kinds of children's songs for learning English, the teacher must also be good at singing songs with body movements and cheerful facial expressions.

Before implementing songs for teaching, the teacher should pay attention to several steps suggested by Brewster (2002) regarding the framework for using songs for language teaching to young learners, including the following:

1. Make the context, and in this case, the teacher needs to explain the purpose and background information.

2. Teach vocabulary that is considered necessary in advance using visual aids, actions/movements, realia or imitation, and puppets.

3. Listen to the cassette or sing a song so that students can listen, show their understanding, and begin to get familiar with the rhythm and tone. 
4. Do advanced listening activities.

5. Pay attention to pronunciation, for example, to identify intonation patterns, words, or syllables that are stressed (stressed words or syllables).

6. Invite students to listen to, repeat, and practice singing and learning the song. Please encourage them to use body movements and facial expressions.

7. Give written notes to the text of the song. In this regard, the teacher does not necessarily have to provide complete notes on the songs he teaches. Teachers can package them into exciting and learning-oriented activities. For example, students are asked to make their version of the song (change according to context), students can listen to and complete the parts of the song that were removed first sort songs, compose words from 2 different songs, or match pictures with writing.

8. Invite students to compare it with similar types in their mother tongue or national language.

9. Present it either together, individually, in groups, in pairs

Pre-service teachers should master those steps before they teach English by using the song as a method. Even though it sounds simple, as a creative teacher, she/he must pay attention to the appropriate syntax. So, learning activities can be directed and controlled.

The three aspects above are the main tools that are important for an English teacher as a foreign language. while mastery of language skills itself is the main point, mastery of pedagogy and shrewdness in choosing learning tools through literature are also points that should be mastered. So, learning English can be more fun so that mastery of the target language can be achieved. Therefore, for some pre-service English teachers who are preparing to have a profession as a teacher in the future, they need to be open to other sciences. Although the main point is teaching language skills, there are other aspects that preservice teachers need to master. Success in achieving these aspects of course does not come from the pre-service teachers themselves, but also from the institutions or universities where they study and prepare to become real teachers.

Such as Popper's view that open society needs to engage in critical thinking, which requires freedom of thought and expression and cultural and legal institutions that can facilitate this. Such as Popper's view that open society needs to engage in critical thinking, which requires freedom of thought and expression and cultural and legal institutions that can facilitate this. Institutions originally need to facilitate the learning of pre-service teachers for EYL with a curriculum that is relevant to existing cultural conditions. Considering that 
English is a foreign language and the educators are also users of English as a foreign language, the target of preparing to produce English teachers for young learners should not only be language skills but also how they can teach the foreign language smoothly.

\section{CONCLUSION}

Overall, the discussion of Karl Popper's falsifying epistemology theory that all science develops through conjecture and refutation has enormous implications for education. Especially for prospective educators such as pre-service teachers who are currently studying at a university, they need to become Popperian teachers, which means they can receive information and think critically about all changes. The critical thing that is meant is not rejection or easy acceptance, but how the information received can be proven false or true. Therefore, as prospective teachers in the future, they need to prepare themselves for their profession, such as linguistic proficiency, pedagogical knowledge, and skills in using literature as a means of teaching English as a foreign language to young learners. Pedagogy is the knowledge for pre-service teachers to be able to teach well. Apart from mastery of pedagogy, pre-service teachers must have good linguistic skills in its application. The last aspect is literature, which is needed by prospective teachers to support two other aspects that have been mastered in learning English to children. This article contributes to a significant understanding of pre-service English teachers for young EFL students with regard to their preparation for future teachers. This article recommends the next researchers to discuss in more depth other aspects that pre-service teachers need to become teachers.

\section{REFERENCES}

[1] Adger, C. T., Snow, C. E., \& Christian, D. (Eds.). (2018). What teachers need to know about language. Multilingual Matters.

[2] Akiba, M. (2011). Identifying program characteristics for preparing pre-service teachers for diversity. Teachers College Record, 113(3), 658-697.

[3] Asrial, A., Syahrial, S., Kurniawan, D. A., Subandiyo, M., \& Amalina, N. (2019). Exploring Obstacles in Language Learning among Pre-service primary School Teacher. International Journal of Evaluation and Research in Education, 8(2), 249-254.

[4] Babatsouli, E. (Ed.). (2020). On Under-reported Monolingual Child Phonology. Multilingual Matters.

[5] Beck, C., \& Kosnik, C. (2000). Associate teachers in pre-service education: Clarifying and enhancing their role. Journal of education for teaching, 26(3), 207-224.

[6] Betz, E. M., \& Huth, T. (2014). Beyond grammar: Teaching interaction in the German language classroom. Die Unterrichtspraxis/Teaching German, 47(2), 140-163.

[7]Brandt, J. O., Barth, M., Merritt, E., \& Hale, A. (2020). A matter of connection: The 4 Cs of learning in pre-service teacher education for sustainability. Journal of Cleaner Production, 279, 123749. 
[8] Brewster, J., Ellis, G., Girard, D. 2002. The Primary English Teacher's Guide. England: Penguin English.

[9] Caner, M. (2009). A study on blended learning model for teaching practice course in preservice English language teacher training program. Unpublished Doctoral Dissertation. Anadolu University, Graduate School of Educational Sciences, Eskisehir, Turkey.

[10] Clandfield, L. (2008). Culture in ELT: Which C? Whose C. Teaching of English as A Second Language of Ontario, 34(3), 4-8.

[11] Copland, F., Garton, S., \& Burns, A. (2014). Challenges in teaching English to young learners: global perspectives and local realities. Tesol Quarterly, 48(4), 738-762.

[12] Csíkos, C., \& Szitányi, J. (2020). Teachers' pedagogical content knowledge in teaching word problem-solving strategies. ZDM, 52(1), 165-178.

[13] Darwis, N., \& Hasanah, U. (2020). The Effectiveness of Using Teaching English for Young Learner (TEYL) Module for Pre-service Teacher Based on Teacher Training Approach. IDEAS: Journal on English Language Teaching and Learning, Linguistics and Literature, 8(1).

[14] De Jong, E. J., \& Harper, C. A. (2005). Preparing mainstream teachers for Englishlanguage learners: Is being a good teacher good enough?. Teacher Education Quarterly, 32(2), 101-124.

[15] De Swaan, A. (2013). Words of the world: The global language system. John Wiley \& Sons.

[16] Diane, L. (2019). Techniques and principles in language teaching.

[17] Durriyah, T. L. (2014). Reading and responding to children's literature: A qualitative study of Indonesian pre-service teachers' response in an Introduction to Children's Literature course (Doctoral dissertation, The Ohio State University).

[18] El-Naggar, B. E. E. S., Ibrahim, M. H., \& Marzouq, A. A. Optimizing Conversation Analysis (CA) to Develop EFL Pre-serviceTeachers' Syntactic Proficiency.

[19] Ernest, P., Skovsmose, O., Paul van Bendegem, J., Bicudo, M., Miarka, R., Kvasz, L., \& Moeller, R. (2016). The philosophy of mathematics education. Springer Nature.

[20] Feiman-Nemser, S., \& Buchmann, M. (1986). The first year of teacher preparation: Transition to pedagogical thinking?. Journal of curriculum studies, 18(3), 239-256.

[21] Galindo Torres, L. A. (2020). Foreign Language Learning in Early Grades: Teaching Strategies for Classroom Instruction.

[22] Garton, S., Copland, F., \& Burns, A. (2011). Investigating global practices in teaching English to young learners. ELT Research papers, 11(1), 1-24.

[23] Gebhard, J. G. (2006). Teaching English as a foreign or second language: A teacher self-development and methodology guide. University of Michigan Press.

[24] Gerson, G. (2019). Nationality in the open society: Popper versus Hayes and Kohn. Nations and Nationalism, 25(1), 208-228.

[25] Ghazali, S. N., Setia, R., Muthusamy, C., \& Jusoff, K. (2009). ESL Students' Attitude towards Texts and Teaching Methods Used in Literature Classes. English language teaching, 2(4), 51-56.

[26] Hagger, H., \& Malmberg, L. E. (2011). Pre-service teachers' goals and future-time extension, concerns, and well-being. Teaching and Teacher Education, 27(3), 598-608.

[27] Hollie, S. (2017). Culturally and linguistically responsive teaching and learning: Classroom practices for student success. Teacher Created Materials.

[28] Huang, R., Spector, J. M., \& Yang, J. (2019). Linking learning objectives, pedagogies, and technologies. In Educational Technology (pp. 49-62). Springer, Singapore.

[29] Itoi, E. (2014). Pre-service EFL teachers' possible selves: A longitudinal study of the shifting development of professional identities. Temple University. 
[30] Karabuz, O., \& Ogan-Bekiroglu, F. (2020). Pre-Service Teachers' Technological Pedagogical Content Knowledge (TPCK) Related to Calculator-Based Laboratory and Contextual Factors Influencing Their TPCK. Journal of Curriculum and Teaching, 9(3), $57-75$.

[31] Kosnik, C., \& Beck, C. (2009). Priorities in teacher education: The 7 key elements of pre-service preparation. Routledge.

[32] Ladson-Billings, G. J. (1999). Chapter 7: Preparing teachers for diverse student populations: A critical race theory perspective. Review of research in education, 24(1), 211-247.

[33] Ladson-Billings, G. (2004). Crossing over to Canaan: The journey of new teachers in diverse classrooms. John Wiley \& Sons.

[34] Larsen-Freeman, D. (2000). Techniques and principles in language teaching. Oxford University.

[35] Li, D., \& Liu, Y. (2020). International Counseling Doctoral Students' Teaching Preparation: A Phenomenological Study. Counselor Education and Supervision, 59(3), 200-215.

[36] Li, G. (2011). The Role of Culture in Literacy, Learning, and Teaching. In Handbook of Reading Research, Volume IV (pp. 541-564). Routledge.

[37] Lysvik, J. K. (2020). Where does naturalness in phonology come from?-Insights from Artificial Language Learning.

[38] Mizell, J. D. (2020). Apprenticeship of pre-service teachers through culturally sustaining systemic functional linguistics. Language and Education, 1-17.

[39] Motteram, G. (2013). Innovations in learning technologies for English language teaching. British Council.

[40] Murphy, K. A., \& Diehm, E. A. (2020). Collecting words: A clinical example of a morphology-focused orthographic intervention. Language, Speech, and Hearing Services in Schools, 51(3), 544-560.

[41] Nind, M., \& Lewthwaite, S. (2020). A conceptual-empirical typology of social science research methods pedagogy. Research Papers in Education, 35(4), 467-487.

[42] Numonjonov, S. D. (2020). Innovative methods of professional training. ISJ Theoretical \& Applied Science, 1(81), 747-750.

[43] O'MALLEY, J. M., Chamot, A. U., Stewner-Manzanares, G. L. O. R. I. A., Russo, R. P., \& Küpper, L. (1985). Learning strategy applications with students of English as a second language. TESOL Quarterly, 19(3), 557-584.

[44] Onwuegbuzie, A. J., \& Frels, R. (2016). Seven steps to a comprehensive literature review: A multimodal and cultural approach. Sage.

[45] Oxford, R. L. (2016). Teaching and researching language learning strategies: Selfregulation in context. Taylor \& Francis.

[46] Parvin, P. (2010). Karl Popper. Bloomsbury Publishing USA.

[47] Peacock, M. (2001). Pre-service ESL teachers' beliefs about second language learning: A longitudinal study. System, 29(2), 177-195

[48] Pentury, H. J., \& Anggraeni, A. D. (2019). Enriching Teachers' Pedagogical Strategy using the Role of Global Competence Learning Model. Jurnal Pendidikan Progresif, 9(1), 29-39.

[49] Perihan, K., \& Mehmet, Ç. (2020). Pre-service teachers' cognition on student understanding in the EFL language classroom.

[50] Pinter, A. (2017). Teaching young language learners. Oxford University Press.

[51] Popper, K. (2014). After the open society: Selected social and political writings. Routledge. 
[52] Powell, B. J., Waltz, T. J., Chinman, M. J., Damschroder, L. J., Smith, J. L., Matthieu, M. M., ... \& Kirchner, J. E. (2015). A refined compilation of implementation strategies: results from the Expert Recommendations for Implementing Change (ERIC) project. Implementation Science, 10(1), 21.

[53] Richards, J. C., \& Farrell, T. S. C. (2005). Professional development for language teachers: Strategies for teacher learning. Ernst Klett Sprachen.

[54] Richards, J. C., \& Rodgers, T. S. (2014). Approaches and methods in language teaching. Cambridge university press.

[55] Saafin, S. (2019). How to Help Students Learn English Better:" Towards Creating a Language Learning Culture". English Language Teaching, 12(9), 126-136.

[56] Saito, K., Trofimovich, P., \& Isaacs, T. (2016). Second language speech production: Investigating linguistic correlates of comprehensibility and accentedness for learners at different ability levels. Applied Psycholinguistics, 37(2), 217-240.

[57] Samson, J. F., \& Collins, B. A. (2012). Preparing All Teachers to Meet the Needs of English Language Learners: Applying Research to Policy and Practice for Teacher Effectiveness. Center for American Progress.

[58] Senjaya, W. (2008). Strategi Pembelajaran. Berorientasi Standar Proses Pendidikan.

[59] Setiyadi, A. G. (2020). Teaching English as a foreign language.

[60] Shanahan, T. (2020). Limiting Children to Books They Can Already Read: Why It Reduces Their Opportunity to Learn. American Educator, 44(2), 13.

[61] Stanley, P., \& Stevenson, M. (2017). Making sense of not making sense: Novice English language teacher talk. Linguistics and Education, 38, 1-10.

[62] Suparsa, I. N., Mantra, I. B. N., \& Widiastuti, I. A. M. S. (2017). Developing learning methods of Indonesian as a foreign language. International journal of social sciences and humanities, 1(2), 51-57.

[63] Tarnoto, et al. (2016). Modul Bermain Peran “Aku Sayang Temanku. Fakultas Psikologi Universitas Ahmad Dahlan

[64] Teo, P. (2019). Teaching for the 21st century: A case for dialogic pedagogy. Learning, Culture and Social Interaction, 21, 170-178.

[65] Timmerman, G. (2009). Teacher educators modeling their teachers?. European journal of teacher education, 32(3), 225-238.

[66] Wicaksono, A., dkk. 2016. Teori Pembelajaran Bahasa: Suatu Catatan Singkat Edisi Revisi. Yogyakarta: Garudhawaca.

[67] Widyawati, A., \& Usman, O. (2019). The Influence of Learning Media, Teaching Methods, E-Learning and Teacher's Creativity of Learning Interest. E-Learning and Teacher's Creativity of Learning Interest (December 27, 2019).

[68] Yallop, C., \& Fletcher, J. (2007). An introduction to phonetics and phonology.

[69] Zarrinabadi, N. (2014). Communicating in a second language: Investigating the effect of teacher on learners' willingness to communicate. System, 42, 288-295.

[70] Zhang, L. J., Thomas, N., \& Qin, T. L. (2019). Language learning strategy research in system: looking back and looking forward. System, 84, 87-92. 